\title{
Biotechnological approaches to determine the impact of viruses in the energy crop plant Jatropha curcas
}

\author{
Rose C Ramkat ${ }^{\dagger}$, Alberto Calari ${ }^{\dagger}$, Fatemeh Maghuly and Margit Laimer
}

\begin{abstract}
Background: Geminiviruses infect a wide range of plant species including Jatropha and cassava both belonging to family Euphorbiaceae. Cassava is traditionally an important food crop in Sub - Saharan countries, while Jatropha is considered as valuable biofuel plant with great perspectives in the future.

Results: A total of 127 Jatropha samples from Ethiopia and Kenya and 124 cassava samples from Kenya were tested by Enzyme-Linked Immunosorbent Assay (ELISA) for RNA viruses and polymerase chain reaction for geminiviruses. Jatropha samples from 4 different districts in Kenya and Ethiopia (analyzed by ELISA) were negative for all three RNA viruses tested: Cassava brown streak virus (CBSV), Cassava common mosaic virus, Cucumber mosaic virus, Three cassava samples from Busia district (Kenya) contained CBSV. Efforts to develop diagnostic approaches allowing reliable pathogen detection in Jatropha, involved the amplification and sequencing of the entire DNA A molecules of 40 Kenyan isolates belonging to African cassava mosaic virus (ACMV) and East African cassava mosaic virus - Uganda. This information enabled the design of novel primers to address different questions: a) primers amplifying longer sequences led to a phylogenetic tree of isolates, allowing some predictions on the evolutionary aspects of Begomoviruses in Jatrophia; b) primers amplifying shorter sequences represent a reliable diagnostic tool. This is the first report of the two Begomoviruses in J. curcas. Two cassava samples were co - infected with cassava mosaic geminivirus and CBSV. A Defective DNA A of ACMV was found for the first time in Jatropha.

Conclusion: Cassava geminiviruses occurring in Jatropha might be spread wider than anticipated. If not taken care of, this virus infection might negatively impact large scale plantations for biofuel production. Being hosts for similar pathogens, the planting vicinity of the two crop plants needs to be handled carefully.
\end{abstract}

\section{Introduction}

Geminiviruses are a group of plant viruses that contain circular single stranded (ss) DNA genomes encapsidated in small twinned icosahedral capsids [1]. They infect a wide range of plant species and are responsible for considerable crop losses [2]. Members of this virus family have been classified into four genera: Begomovirus, Curtovirus, Mastrevirus, and Topocuvirus, depending on genome organization, host range and type of insect vectors [3]. The genome of cassava mosaic geminivirus (CMG) belonging to the genus Begomovirus consist of two components termed DNA A and DNA B each of

\footnotetext{
* Correspondence: margit.laimer@boku.ac.at

+ Contributed equally

Plant Biotechnology Unit, IAM, VIBT, BOKU, Muthgasse 18, A - 1190 Vienna,
} Austria

C 2011 Ramkat et al; licensee BioMed Central Ltd. This is an Open Access article distributed under the terms of the Creative Commons Attribution License (http://creativecommons.org/licenses/by/2.0), which permits unrestricted use, distribution, and reproduction in any medium, provided the original work is properly cited.
2.7 - $3.0 \mathrm{~kb}[1,4]$. The virus DNA A plus strand encodes the coat protein (CP/AV1) essential for viral transmission by whiteflies (Bemisia tabaci) [1,5]. There are three overlapping open reading frames (ORFs) on the complementary strand, of which the replication associated protein (Rep/AC1) is absolutely required for the replication of both genomic components [6,7]. The replication enhancer protein (REn/AC3) is not essential for infection but enhances viral DNA accumulation [7]. The transcriptional activator protein ( $\mathrm{TrAP} / \mathrm{AC} 2)$ is required for the transcription - activation of plus strand gene transcription, and is also involved in suppression of post - transcriptional gene silencing (PTGS) [8,9]. The functions of two other DNA A encoded proteins AV2 and AC4 remains unclear although possible roles in movement (AV2), pathogenicity and PTGS (AC4) have been

\section{Biomed Central}


demonstrated $[9,10]$. DNA B encodes the movement protein $(\mathrm{BC} 1 / \mathrm{MP})$ and a nuclear shuttle protein (BV1/ NSP) required for cell - to - cell and long distance spread of virus in host plant [1]. Both DNAs contain a 200-250 bp region of high sequence homology known as the common region which is a part of a large intergenic region (IR) that contains the origin of replication [4].

Seven species of Begomovirus have been identified so far in association with cassava mosaic disease (CMD) in Africa: African cassava mosaic virus (ACMV), East African cassava mosaic virus (EACMV), East African cassava mosaic Cameroon virus (EACMCV), East African cassava mosaic Kenya virus (EACMKV), East African cassava mosaic Malawi virus (EACMMV), East African cassava mosaic Zanzibar virus (EACMZV) and South African cassava mosaic virus (SACMV) [11-14]. The distribution of the viruses has become more complex, since they invade new geographical regions and host plants $[14,15]$. This was attributed to their evolution which was more rapid than anticipated through mutational changes, recombination of double stranded (ds) DNA intermediates and re - assortment of gene components (pseudo - recombination) [12-17]. In fact, recombination played a role in the emergence of a new geminivirus that resulted in severe epidemics almost eliminating cassava (Manihot esculenta) in Uganda and Central Africa $[12,18]$. The symptom severity (due to synergism) was linked to the occurrence of East African cassava mosaic virus - Uganda (EACMV - UG) arising from recombination of EACMV and ACMV) [12]. Synergism refers to a situation where one virus affects a co - infecting virus by allowing its increased accumulation in the host plant by facilitating its replication, its movement to tissues that otherwise would not be invaded, resulting in more severe symptoms than caused by each single infection [19]. Synergism between EACMV and ACMV is due to a selective advantage conferred by each partner linked to post transcriptional gene silencing (PTGS). In plants, PTGS operates as an adaptive immune system targeted against viruses [20]. To counteract this defence system, viruses have developed suppressor proteins [21]. ACMV and EACMV - UG possess two PTGS suppressors AC4 and $\mathrm{AC} 2$ respectively, with differential roles that target different steps in RNA silencing in a temporal and spatial manner $[8,10,21,22]$. Therefore using more than one type of PTGS suppressor provides an advantage to viruses synergistically interacting in mixed infections, leading to more severe symptoms $[9,10]$. Furthermore, geminiviruses may be associated with small sub genomic DNA molecules termed as Defective (Def) DNAs, which are the result of partial deletion to approximately half the genome, even disrupting genes [23,24]. They may also result from sequence duplication, inversion or rearrangement of viral DNA, and recombination between DNA A and DNA B components [25].

Additionally, Cassava brown streak disease (CBSD), caused by Ipomoviruses (family Potyviridae), has been reported to lead to severe yield losses in cassava plantations in Africa [26-28].

Both host plants under study, cassava and Jatropha, belong to the family Euphorbiaceae. Jatropha is a drought resistant shrub native in tropical America, but is now widely grown in many tropical and subtropical regions for biodiesel production [29,30]. Based on the genetic relationship of cassava and Jatropha and the detrimental impact of Begomoviruses in cassava, the question arose, whether Jatropha would be threatened by comparable epidemics, if planted on larger extensions, or in spatial neighbourhood. Therefore it was necessary to develop diagnostic approaches allowing reliable pathogen detection in Jatropha, which involved the amplification and sequencing of the entire DNA A molecules of 40 Kenyan isolates belonging to ACMV and EACMV - UG. This information enabled the design of novel primers to address different questions: a) primers amplifying longer sequences led to a phylogenetic tree of isolates, allowing some predictions on the evolutionary aspects of Begomoviruses in Jatropha; b) primers amplifying shorter sequences represent a reliable diagnostic tool, given that so far only limited serological tests are available.

\section{Results}

Symptomatology

Jatropha plants growing in the field showed symptoms ranging from reduced leaf size, malformation and severe dwarfing of 1 - 3 year old plants. Symptoms on Jatropha plants growing in the glasshouse were registered after 3 weeks as severe leaf yellowing coupled with browning of newly formed leaves, leaf malformation, reduced leaf size, mild to severe chlorotic specks and chlorosis in some plants. Drying (like burning) and rolling of leaves from tips was observed on 3 months old cuttings. In cassava the symptoms observed in plants the field grown and maintained in the glasshouse were similar: mosaic, severe reduction and distortion of leaves, and stunted growth of some plants.

\section{Virus detection by Enzyme-Linked Immunosorbent Assay (ELISA)}

The Jatropha samples did not contain any of the three RNA viruses tested: Cassava brown streak virus (CBSV), Cucumber mosaic virus (CMV) and Cassava common mosaic virus (CsCMV) when analyzed by ELISA (see Additional file 1 Table S1). Also the cassava samples were negative for CMV and CsCMV. In fact, only three 
cassava samples from Busia district contained CBSV, as detected by ELISA (see Additional file 2 Table S2).

\section{Virus detection by Polymerase chain reaction (PCR)}

All Jatropha and cassava samples were tested by PCR for the presence of geminiviruses. The primer pair JC3F and JC4R amplified longer sequences of DNA A which were used the construct a phylogenetic tree. Primer pair JC6F and JC2R amplified a shorter sequence of $380 \mathrm{bp}$ from $\mathrm{AC} 1, \mathrm{AC} 2$ and $\mathrm{AC} 3$ and distinguished reliably positive from negative samples.

When symptomatic Jatropha samples from Kenya were tested with primer pair JC3F and JC4R, 69\% were positive. The primers were able to further detect virus in $67 \%$ of asymptomatic samples. For symptomatic Jatropha samples collected from Ethiopia, 61\% tested positive with the primers JC6F and JC2R (see Additional file 1 Table S1). With the same primers, $75 \%$ of symptomatic samples from Kenya tested positive while $20 \%$ of asymptomatic samples were detected positive.

For cassava, when symptomatic samples were amplified with primer pair JC3F and JC4R, 63\% were positive while all asymptomatic samples tested negative. The primer pair JC6R and JC2R tested all (100\%) symptomatic samples positive while only $6 \%$ of asymptomatic plants were positive (see Additional file 2 Table S2).

Samples testing positive with primer JC6R and JC2R yielded bands with different intensity on gel electrophoresis, which were classified as weak positive $(+)$, moderate positive $(++)$ and strong positive $(+++)$ (see Additional file 1 Table S1 and Additional file 2 Table S2). Only 2 cassava samples were co - infected with CBSV and CMG (see Additional file 2 Table S2).

\section{Reverse transcription - polymerase chain reaction (RT- PCR)}

All Jatropha samples tested negative for CMV and CBSV. The cassava samples were negative for CMV and only one sample tested positive for CBSV.

\section{Sequences and phylogenetic analysis of DNA A}

Complete nucleotide sequences of forty DNA A components typical of Begomoviruses in the Kenyan samples were determined, of which 34 sequences were from Jatropha and 6 from cassava (see Additional file 3 Table S3).

Figure 1 shows a phylogenetic comparison of the complete DNA A sequences of the Begomoviruses isolates

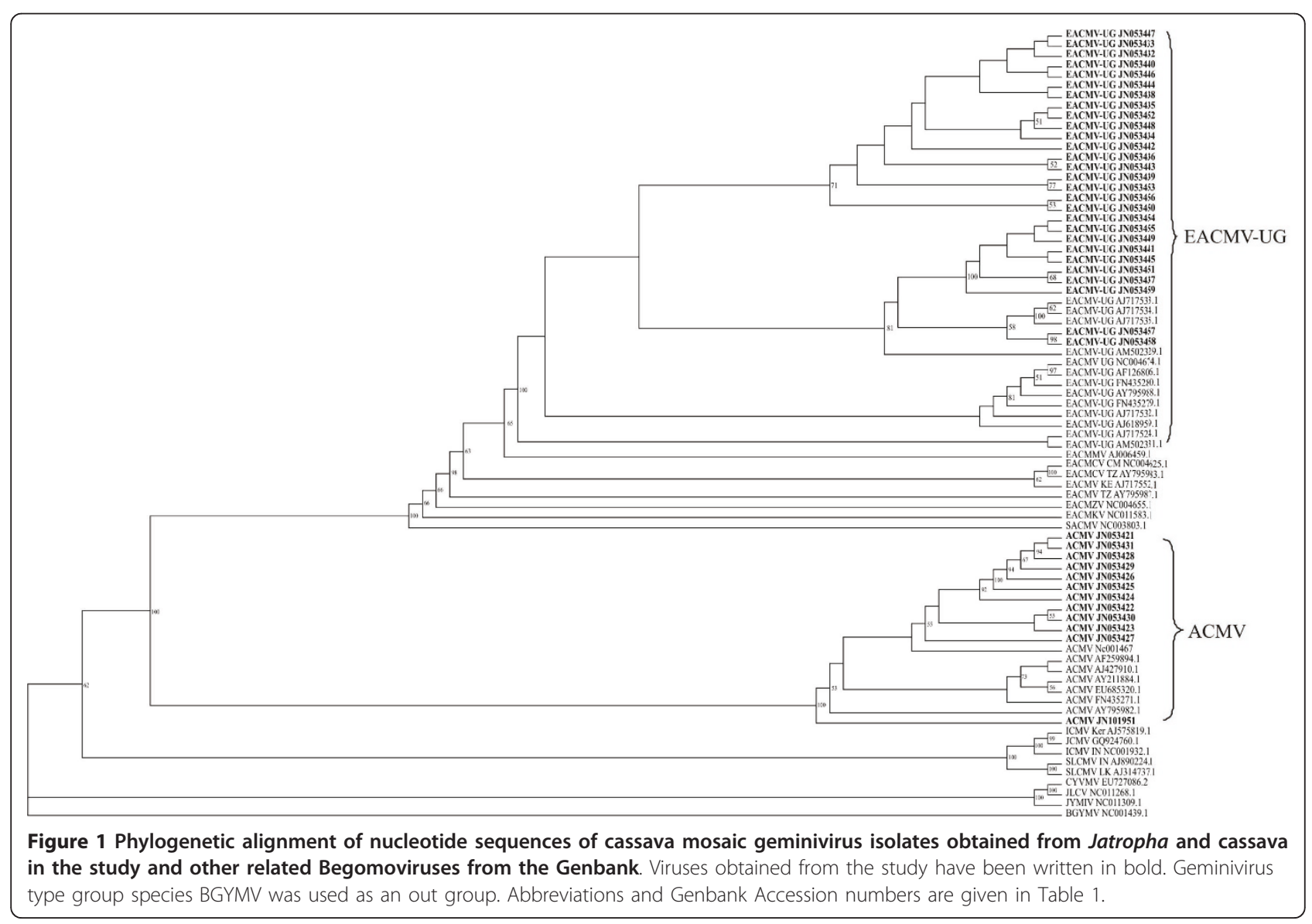


obtained from Jatropha and cassava in this study and other Begomoviruses associated with the two host plants publicly available in the Genbank (Table 1) [12-14,16,17,31-40]. Phylogenetic analyses clearly indicated that they belong to CMG involved in CMD as they had close identities with sequences already deposited in public databases. All viruses characterised in this study could be grouped with two previously identified Begomoviruses found in cassava in Western Kenya, namely EACMV - UG and ACMV, but not with the species EACMKV [GenBank: NC011583.1], EACMZV [GenBank: NC004655.1] and strain EACMV - KE [GenBank: AJ717552.1], which were found in Kenya previously [14]. The viruses also did not group with EACMV - TZ [GenBank: AY795987.1], EACMCV - TZ [GenBank: AY795983.1], EACMCV - CM [GenBank: NC004625.1], EACMMV [GenBank: AJ006459.1], SACMV [GenBank: NC003803.1], ICMV IN [GenBank: NC001932.1], ICMV - ker [GenBank: AJ575819.1], SLCMV - IN [GenBank: AJ890224.1] and SLCMV - LK [GenBank: AJ314737.1] found elsewhere in Africa and Asia [12,13,36-38]. No close relationship was shown between the viruses and Jatropha begomoviruses from Asia and South America; JCMV [GenBank: GQ924760.1], CYVMV [GenBank: EU727086.2], JYMIV [GenBank: NC011309.1] and JLCV [GenBank: NC011268.1].

The first group of viruses comprises ACMV, showing nucleotide (nt) identity from 95\% (isolate JN053426) to 97.3\% (isolates JN053431 and JN053430) with the ACMV reference sequence [GenBank: NC001467.1] (see Additional file 3 Table S3). The second group are closely related to, but distinct from the strains EACMV - KE and EACMV - TZ. The sequences showed approximately $90.7 \%$ nt identity (JN053450) to 92.3\% nt identity (JN053440 and JN053444) with the EACMV - KE [GenBank: AJ717552.1] and only 90\% nt identity (JN053451, JN053441, JN053452 and JN053453) to $90.5 \%$ nt identity (JN053433, JN053440, JN053442, JN053444 and JN053446) with EACMV TZ [GenBank: A1795987.1]. To indicate that they are clearly isolates of the strain EACMV - UG, they had high nt identity ranging from approximately $94.1 \%$ (isolate JN053439) to $98.7 \%$ (isolates JN053440, JN053442 and JN05344) with the EACMV - UG [GenBank: NC004674.1] reference sequence (see Additional file 3 Table S3).

The viruses infecting Jatropha in Western Kenya occur on overlapping territories, since ACMV and EACMV - UG were both found in all the districts analysed (see Additional file 3 Table S3). EACMV - UG occurred with a higher prevalence than ACMV. Generally speaking, out of 34 viral sequences found in Jatropha 24 (71\%) were EACMV - UG, while 10 (27\%) were ACMV. In Busia, a district neighbouring Uganda,
EACMV - UG was most prevalent with 15/24 (62.5\%) compared to $7 / 24(29 \%)$ and only $2 / 24$ (8\%) from Kakamega and Siaya respectively. ACMV was found more frequently with $6 / 10(60 \%)$ on samples from Kakamega district, compared to 2/10 (20\%) from Siaya and Busia respectively.

\section{ACMV Def DNA A}

A Def DNA A was present in a Jatropha leaf samples collected from Western Kenya. PCR analyses with primer JC3F and JC4R of sample K1J5 amplified the expected $2.8 \mathrm{~kb}$ of a near full length DNA A component of the Begomovirus sequence and an additional shorter fragment (Figure 2). Sequencing of the smaller fragment revealed a size of $1420 \mathrm{bp}$, which was named Def K1J5. This Def (Genbank JN101951) showed 96.6\% nt identity with the ACMV reference sequence [GenBank NC001467.1] and a low nt similarity (69.7\%) with the EACMV - UG reference sequence [Genbank NC004674.1] (see Additional file 3 Table S3). The complete sequences of DNA A components of ACMV reference sequence [GenBank NC001467.1] was used for size comparison with the ORFs of Def K1J5. On the virion sense strand, AV1 and AV2 were entirely missing. In the complementary sense strand, AC4 was the only intact gene at $422 \mathrm{bp}$ while $\mathrm{AC} 1$ was $1070 \mathrm{bp}$ long. Two ORFs, AC2 and AC3, which are found in DNA A of CMGs, had a size of 326 bp and 178 bp respectively (Figure 3). The IR contained the first $11 \mathrm{bp}$ of the replication site of geminiviruses.

\section{Discussion}

Cultivated cassava is believed to be the principle reservoir for CMD associated begomoviruses because of its perennial growth and scale of production. However, alternative hosts have been identified, including Manihot glaziovii Müll, a wild relative of cassava native to Brazil [35], Senna occidentalis, Leucana leucocephala, Combretum confertum, Centrosema pubescens and Pueraria javanica [31,32]. A strain of Cassava latent geminivirus (CLV - V) was previously isolated from naturally infected Jatropha multifida growing in the Coastal districts of Kenya [41]. First reports on geminivirus infections on J. curcas indicated the occurrence of Jatropha curcas virus closely related to Cassava mosaic virus in India, reaching a disease incidence from 25 to $47 \%$ $[30,42,43]$. Phylogenetic analyses of the virus genome showed that Jatropha curcas mosaic disease (JCMD) is caused by Jatropha curcas virus, a new strain of Indian cassava mosaic virus (ICMV) [30]. Jatropha is further host of CMV (family Bromoviridae Cucumovirus) [44]. In this study, we report for the first time the detection of Begomovirus: ACMV and EACMV - UG in Jatropha. Furthermore, a defective molecule derived from DNA A 


\begin{tabular}{|c|c|c|c|}
\hline Virus & Abbreviation & Genbank accession number & Reference \\
\hline \multirow[t]{7}{*}{ African cassava mosaic virus } & ACMV & FN435271.1 & [31] \\
\hline & ACMV & EU685320.1 & [32] \\
\hline & ACMV & AF259894.1 & {$[17]$} \\
\hline & ACMV & AJ427910.1 & [unpublished; Briddon] \\
\hline & ACMV & AY211884.1 & [16] \\
\hline & ACMV & NC001467.1 & [33] \\
\hline & ACMV & AY795982.1 & [13] \\
\hline Bean golden yellow mosaic virus & BGYMV & NC001439.1 & [34] \\
\hline Croton yellow vein mosaic virus & CYVMV & EU727086.2 & [unpublished; Raj et al.] \\
\hline East African cassava mosaic Cameroon virus - Cameroon & EACMCV - CM & NC004625.1 & [16] \\
\hline East African cassava mosaic Cameroon virus - Tanzania & EACMCV - TZ & AY795983.1 & {$[13]$} \\
\hline East African cassava mosaic virus - Kenya & EACMV - KE & AJ717552.1 & [14] \\
\hline East African cassava mosaic virus - Tanzania & EACMV - TZ & AY795987.1 & [13] \\
\hline \multirow[t]{13}{*}{ East African cassava mosaic virus - Uganda } & EACMV - UG & AJ618959.1 & {$[35]$} \\
\hline & EACMV - UG & FN435279.1 & {$[31]$} \\
\hline & EACMV - UG & NC004674.1 & [17] \\
\hline & EACMV - UG & AJ717524.1 & [14] \\
\hline & EACMV - UG & AJ717532.1 & [14] \\
\hline & EACMV - UG & AJ717533.1 & [14] \\
\hline & EACMV - UG & AJ717534.1 & [14] \\
\hline & EACMV - UG & AJ717535.1 & [14] \\
\hline & EACMV - UG & AM502329.1 & {$[35]$} \\
\hline & EACMV - UG & AM502331.1 & {$[35]$} \\
\hline & EACMV - UG & AF126806.1 & [17] \\
\hline & EACMV - UG & FN435280.1 & [31] \\
\hline & EACMV - UG & AY795988.1 & [13] \\
\hline East African cassava mosaic Kenya virus & EACMKV & NC011583.1 & [14] \\
\hline East African cassava mosaic Malawi virus & EACMMV & AJ006459.1 & {$[12]$} \\
\hline East African cassava mosaic Zanzibar virus & EACMZV & NC004655.1 & {$[36]$} \\
\hline Indian cassava mosaic virus - India & ICMV - IN & NC001932.1 & {$[37]$} \\
\hline Indian cassava mosaic virus - Kerela & ICMV - Ker & AJ575819.1 & [38] \\
\hline Jatropha curcas mosaic virus & JCMV & GQ924760.1 & {$[30]$} \\
\hline Jatropha leaf curl virus & JLCV & NC011268.1 & [unpublished; Pal\&Mukherjee] \\
\hline Jatropha yellow mosaic India virus & JYMIV & NC011309.1 & [unpublished; Raj et al.] \\
\hline South African cassava mosaic virus & SACMV & NC003803.1 & [39] \\
\hline Sri Lankan cassava mosaic virus - India & SLCMV - IN & AJ890224.1 & {$[40]$} \\
\hline Sri Lankan cassava mosaic virus - Sri Lanka & SLCMV - LK & AJ314737.1 & {$[38]$} \\
\hline
\end{tabular}

of the bipartite Begomovirus ACMV was detected in $J$. curcas. Also the presence of a co - infection with CMG and CBSV was found in cassava plants.

The phylogenetic tree of the complete DNA A sequences indicates that the ACMV and EACMV - UG isolates were closely related to those isolated previously in Western Kenya [14,33]. From an evolutionary perspective, it is an indication that the geminiviruses infecting Jatropha from the sampled areas are as a result of spread of viruses from an inoculum source occurring where the plants are growing. This is further supported by the idea that the EACMKV, EACMV - KE and EACMZV previously identified [14] from Eastern and
Coastal parts of Kenya were not found to be present in Jatropha, since the viruses have a distinct geographical distribution [14]. Geminivirus dissemination occurs through cuttings or whiteflies. The viruses identified in this study were not closely related with those infecting cassava and Jatropha in other parts of Africa, Asia and South America suggests that there has been no movement of infected Jatropha cuttings and viruliferous whiteflies from other areas to Western Kenya. In fact, recombination results in severe epidemiological consequences such as the emergence of isolates with increased virulence capable of overcoming host resistance or with a host range wider than the original one 


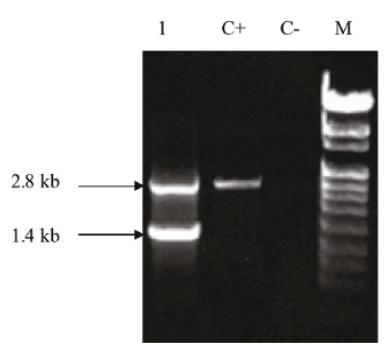

Figure 2 PCR amplification of defective DNA A of ACMV from Jatropha. PCR amplification was performed using primer JC3F and JC4R on DNA extracted from field - grown Jatropha plants. Lane 1 shows the defective DNA A, lane C+ and C-positive and negative controls. Lane $\mathrm{M}=$ marker VIII (Roche Applied Science).

[45]. Recombination and synergism that have long occurred in cassava [12-18] could have led to the current spread of the virus in the field to infect Jatropha plants. The recombinant EACMV - UG was the most prevalent strain virus found whilst the other strains of EACMV were not identified. In line with this are previous claims, that EACMV in Western Kenya has been largely displaced by EACMV - UG, which is considered a more virulent strain [14]. In the current study the presence of EACMV - UG and ACMV on different Jatropha plants in the same field indicates the opportunity for mixed infections. For example plants K4J1 (EACMV - UG isolate JN053453) and K4J2 (ACMV isolate JN053425) (Figure 1) stand close to each other in the same field, hence offering good opportunities for more recombination to occur. EACMV - UG and ACMV are associated with severe synergistic epidemics on cassava that swept through Uganda and continues to affect surrounding countries including Kenya $[14,12,18,46]$. Specifically the two viruses have differentially acting suppressors of PTGS overcoming the hosts defence mechanisms [8-10,20-22]. ACMV (recovery - type) has a strong AC4 suppressor and EACMV - UG (non - recovery - type) has a strong AC2 suppressor causing

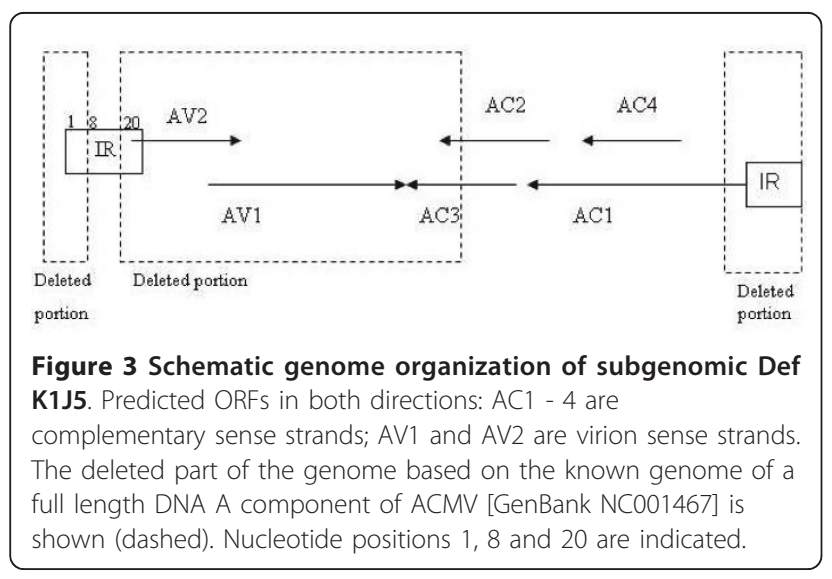

unusually severe symptoms. As a result, ACMV will leave only EACMV - UG to be spread and become the predominant virus in the area $[9,21,47]$. In the absence of a synergistic interaction, only one virus in a co infected plant will become predominant and persist $[9,10,14]$. Synergism may lead to a 10 - 50 fold increase in viral DNA accumulation which substantially increases the potential for a higher efficiency of vector transmission to even infect non cassava host plants $[18,31]$ This might further explain, why the EACMV - UG appears as predominant virus in Jatropha. Co - infection of CMG and CBSV threatens cassava production in Busia distict of Kenya. Recent studies have shown how evolution is shaping the populations of CBSV and Uganda cassava brown streak virus (UCBSV) in cassava causing significant problems [26-28]. Mixed infection results in increase in the titer of one or both viruses and elicits disease symptoms that are more sever than the sum of those induced in single infection $[10,19]$.

In addition to genomic components, smaller sized Def DNA often occurs naturally in geminivirus infected plants [25]. The plant, from which the defective DNA molecule was isolated in the current study, did not display particular symptoms differing from the neighbouring plants growing in the same field, meaning that it could not have been picked up on purpose due to a previous selective decision. The Def DNA molecule found in the plant K1J5 had lost the entire AV1 and AV2 genes and large portions of other genes. Sub genomic Def DNA molecules associated with a number of Begomovirus seem to be fairly uniform in structure and retain their IR and a large portion of AC1 [23], as observed also in this study. These deletions might affect the replication of the molecule and it might depend entirely on its helper virus for replication. Geminivirus Def DNA invariably rely on the respective viruses for replication as observed for Tomato leaf curl virus that lacked an ORF required for replication and encapsidation and were not expected to be capable of autonomous replication, however they were replicating in the presence of the viral DNA [48]. In cassava, Def DNA has been previously reported occurring in DNA A of EACMV and DNA B of ACMV, and were found to be associated with a delay in symptom development and amelioration $[23,24]$. However, no naturally occurring Def DNA A of ACMV has been found previously in Jatropha curcas and we report it for the first time. The role of this small Def DNA molecule in the biology of ACMV in Jatropha in nature is still unclear.

\section{Conclusion}

We have shown for the first time cassava Begomoviruses and their associated sub - genomic Def DNA molecules to be naturally occurring in field growing Jatropha 
plants. The occurrence of the Begomoviruses further poses a challenge in the elimination strategy of CMG in field grown cassava as a result of increase in inoculum from different hosts, and calls for an elimination strategy of the viruses in J. curcas in order to save the crop which is an important biofuel and pharmaceutical crop. Molecular detection techniques showed the presence of geminivirus even in asymptomatic plants. The new natural host (J. curcas) of the two viruses opens new avenues for further recombination of the viruses to occur which indeed becomes a threat both to cassava an important food crop to Sub Saharan countries and Jatropha. There is a possibility of Cassava mosaic virus in Jatropha being more widespread than anticipated, since we have detected it also in Jatropha samples from Ethiopia. This has led to hypothesize that other neighboring countries growing Jatropha could be facing similar challenges with this plant. The primer pair JC6F and JC2R amplifying a sequence of $380 \mathrm{bp}$ allows the detection of Begomoviruses in symptomatic and asymptomatic cassava and Jatropha plants and can therefore be recommended for a large scale screening of field samples.

\section{Methods}

\section{Sample collection}

A total of 127 Jatropha samples from Ethiopia and Kenya and 124 cassava samples from Kenya were used in this study. The Kenyan samples were collected during a survey conducted in September 2009 and November 2010 covering four districts: Kakamega, Siaya, Busia (Western region) and Nakuru (Rift valley region) growing Jatropha and cassava together (Figure 4). Ten plants of Jatropha and cassava showing typical virus symptoms and ten symptomless plants were sampled from five fields in each district. Young leaves were picked from the plants and placed in sample collection tubes over silica gel for further detection of viruses. Two cuttings of approximately $30 \mathrm{~cm}$ long were also taken from 5 symptomatic and 5 asymptomatic plants and planted in glasshouse for future use.

\section{Enzyme-Linked Immunosorbent Assay}

Double Antibody Sandwich ELISA (DAS - ELISA) was performed on all Jatropha and cassava plant accessions to detect the presence of RNA viruses such as: CMV and CsCMV using commercially available kits (DSMZ GmbH, Germany and AC Diagnostics). Triple - Antibody Sandwich - ELISA (TAS - ELISA) was performed to determine the presence of CBSV (DSMZ GmbH, Germany). An ELISA sample was taken as positive, when its OD value was at least three times higher than the negative control. All determinations were run in duplicate.

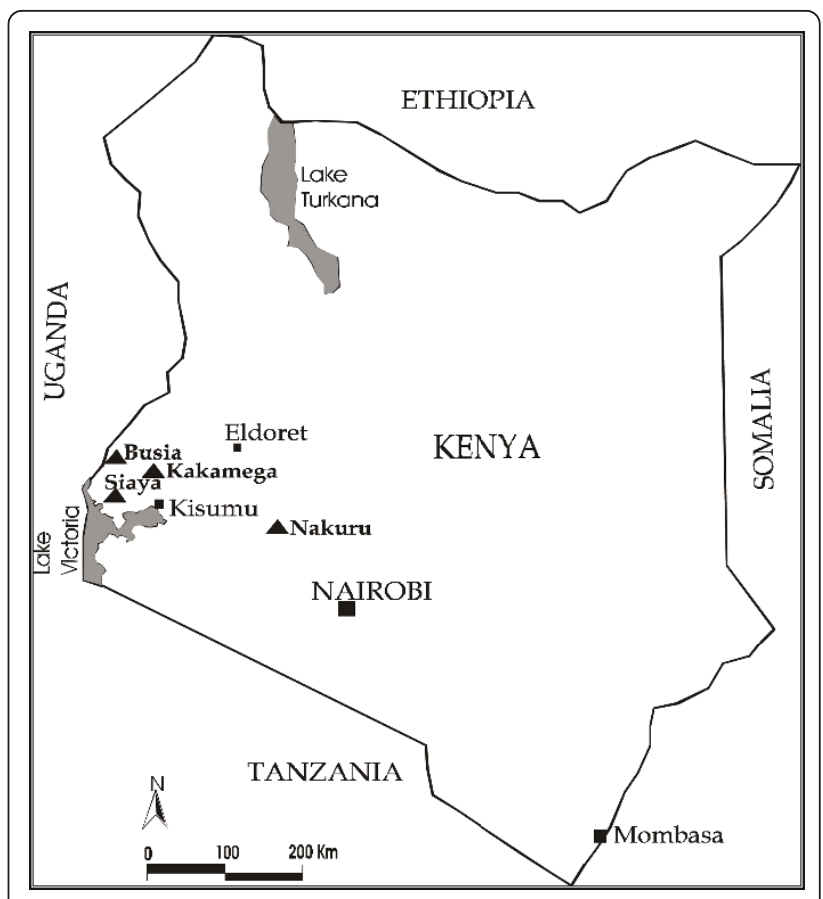

Figure 4 Map of Kenya showing the sites of cassava and Jatropha plant material sampling (black triangles). A survey was conducted in Western Kenya and Rift valley where the two plants are being grown together.

DNA extraction and rolling cycle amplification (RCA)

Total genomic DNA was extracted from leaves using the DNeasy plant Mini Kit (QIAGEN, Hilden, Germany) according to the supplier's instructions. RCA was performed using the TempliPhiTM Kit (Amersham Biosciences) according to the supplier's instructions.

\section{Polymerase chain reaction}

Six different primers were designed (Table 2) based on multiple alignments of full length DNA A sequence of geminivirus from Jatropha and cassava available in the NCBI Genbank to amplify the variable regions to yield longer (2800 bp) and shorter sequences (380 - $1085 \mathrm{bp})$ (Table 3). PCR was conducted in a total volume of $25 \mu \mathrm{l}$

Table 2 List of the oligonucleotides used in this study

\begin{tabular}{ll}
\hline Primer designation* & Primer sequence $\mathbf{( 5}^{\prime}$ to $\mathbf{3}^{\prime} \mathbf{)}$ \\
\hline JC1F & GGAAGATAGTGGGATGCCNCCTTAATTTGAA \\
$\mathrm{JC} 2 \mathrm{R}$ & AARGAATTCATGGGGGCCARAGRGACTGGC \\
$\mathrm{JC} 3 \mathrm{~F}$ & RTCGACGTCATCAATGACGTTGTACCAKGCG \\
$\mathrm{JC} 4 \mathrm{R}$ & GTHGAYCCSCACTAYCTMAARCACTTCAARG \\
$\mathrm{JC} 5 \mathrm{R}$ & GGCCATCCGGTAATATTAWWCGGATGG \\
$\mathrm{JC} 6 \mathrm{~F}$ & CCATTCATTGCTTGAGGAGCAGTG \\
\hline
\end{tabular}

*Primer designation: $\mathrm{F}$ denotes forward $\mathrm{R}$ means reverse.

Primer sequence: $\mathrm{R}$ represents $\mathrm{A}$ or $\mathrm{G} ; \mathrm{K}$ represents $\mathrm{G}$ or $\mathrm{T} ; \mathrm{H}$ represents $\mathrm{A}, \mathrm{C}$ or $T ; Y$ represents $C$ or $T ; S$ represents $G$ or $C ; M$ represents $A$ or $C ; W$ represents $\mathrm{A}$ or $\mathrm{T}$. 
Table 3 Primer combinations and annealing temperatures used to detect geminiviruses in Jatropha curcas and Manihot esculenta in PCR and RCA

\begin{tabular}{|c|c|c|c|c|}
\hline $\begin{array}{l}\text { Forward } \\
\text { primer }\end{array}$ & $\begin{array}{l}\text { Reverse } \\
\text { primer }\end{array}$ & Length & $\begin{array}{c}\text { Annealing } \\
\text { temperature }\end{array}$ & Part of genome amplified by PCR and RCA \\
\hline$J C 1 F$ & $J C 5 R$ & $1085 \mathrm{bp}$ & $60^{\circ} \mathrm{C}$ & PCR : amplifies part of $A C 1$ and entire AC4 \\
\hline $\mathrm{JC} 3 \mathrm{~F}$ & $J C 5 R$ & $971 \mathrm{bp}$ & $63^{\circ} \mathrm{C}$ & PCR : amplifies part of $A C 1$ and entire $A C 4$ \\
\hline$J C 3 F$ & $J C 4 R$ & $2800 \mathrm{bp}$ & $64^{\circ} \mathrm{C}$ & RCA : amplifies the entire DNA A \\
\hline JC3F & $J C 2 R$ & $2800 \mathrm{bp}$ & $64^{\circ} \mathrm{C}$ & RCA : amplifies the entire DNA A \\
\hline $\mathrm{JC} 6 \mathrm{~F}$ & $J C 4 R$ & $410 \mathrm{bp}$ & $55^{\circ} \mathrm{C}$ & PCR : amplifies part of $A C 2$ and $A C 3$ \\
\hline $\mathrm{J} C 6 \mathrm{~F}$ & $J C 2 R$ & $380 \mathrm{bp}$ & $55^{\circ} \mathrm{C}$ & PCR : amplifies part of $A C 1, A C 2$ and $A C 3$ \\
\hline
\end{tabular}

using $2.5 \mu \mathrm{l} 10 \times$ PCR buffer (QIAGEN), $1 \mu \mathrm{l} \mathrm{MgCl}_{2}(25$ $\mathrm{mM}), 0.5 \mu \mathrm{l}$ of each primer (10 pmol), $0.5 \mu \mathrm{l} \mathrm{dNTP}, 0.15$ $\mu$ l HotStarTaq Polymerase (QIAGEN HotStar Plus TM PCR), $1 \mu$ l of total genomic DNA or RCA (1:30) product. Total genomic DNA was used with all the primer sets that amplify shorter sequences while the RCA was used for primer sets that amplify longer sequences (Table 3). For RCA to amplifying longer sequences, the PCR cycling conditions consisted of an initial denaturation step of $95^{\circ}$ $\mathrm{C}$ for $5 \mathrm{~min}$ followed by 35 cycles of $1 \mathrm{~min}$ at $94^{\circ} \mathrm{C}, 1 \mathrm{~min}$ annealing temperature (Table 3 ) and $2 \mathrm{~min}$ at $72^{\circ} \mathrm{C}$. A final step of $10 \mathrm{~min}$ at $72^{\circ} \mathrm{C}$ ended the cycle. For primers pairs amplifying shorter sequences, the difference in PCR conditions was in 30 cycles of $40 \mathrm{~s}$ at $94^{\circ} \mathrm{C}$ and $40 \mathrm{sec}$ annealing temperature (Table 3 ). The PCR products were analyzed by electrophoresis in a $1 \%$ agarose gel. A subsequent purification of full length PCR products was done using QIAquick PCR purification kit (QIAGEN).

\section{Extraction of RNA and RT-PCR}

RT-PCR was performed to detect CBSV and CMV in Jatropha and cassava. Total RNA was extracted from $100 \mathrm{mg}$ of Jatropha and cassava leaves using Spectrum тм plant total RNA kit (SIGMA - ALDRICH) according to the supplier's instructions. cDNA was synthesized from $3 \mu \mathrm{g}$ of genomic RNA using SuperScript II ${ }^{\mathrm{TM}}$ reverse transcriptase primed with oligo $(\mathrm{dT})_{12-18}$ (Invitrogen). The CBSV specific primers CBSV 10F: 5'ATCAGAATAGTGACTGCTGG 3' and CBSV 11R: 5' CCACATTATTATCGTCACCAGG 3' [49] amplifying $230 \mathrm{bp}$ were used for PCR amplification of the cDNA template. The reaction mix and PCR cycling conditions were as performed previous [49]. For CMV detection, Cucumoviruses universal primers CPTALL - 3: 5' GACTGACCATTTTAGCCG 3' and CPTALL - 5: 5' YASYTTTDRGGTTCAATTCC 3' [50] amplifying 940 bp were used for PCR with the reaction mixture and cycling conditions as described previously [50].

\section{Sequence analyses}

Multiple sequence alignments of geminivirus full length DNA A sequences was carried out using the Clustal program (MegAlign, DNAStar). A phylogenetic tree was constructed from multiple alignments by performing a heuristic search. Multiple alignments were analyzed by maximum parsimony with full-length DNA A using Phylogenetic Analysis Using Parsimony (PAUP) and a bootstrap analysis with 1000 replicates was performed.

\section{Additional material}

Additional file 1: Table S1: The summary of Jatropha curcas plants tested for CMG, CBSV, CsCMV and CMV

Additional file 2: Table S2: The summary of Manihot esculenta plants tested for CMG, CBSV, CsCMV and CMV.

Additional file 3: Table S3: Nucleotide sequence identities of DNA A full length of Jatropha and Cassava geminiviruses from Kenya and other geminiviruses available in Genbank.

\section{Acknowledgements}

The support by the Austrian FFG grant Nr. 820132 is acknowledged. RCR was supported by a graduate fellowship from Appear North South Dialogue of the Austrian Development Cooperation (ÖAD). Special thanks to Dr. Laura Karanja and Dr Mabel Mahasi of the Kenya Agriculture Research Institute Njoro for assistance during field work and valuable discussions.

\section{Authors' contributions}

Design and conception of the study, execution of the experiments (RCR, FM, $M L)$, sequence analysis, alignment and phylogeny (RCR, $A C, F M, M L)$. All authors read and approved the final manuscript.

\section{Competing interests}

The authors declare that they have no competing interests.

Received: 10 June 2011 Accepted: 3 August 2011

Published: 3 August 2011

\section{References}

1. Stanley J, Bisaro DM, Briddon RW, Brown JK, Fauquet CM, Harrison BD Rybicki EP, Stenger DC: Family Geminiviridae. In In Virus Taxonomy: Eight Report of the International Committee on Taxonomy of viruses. Edited by: Fauquet CM, Mayo MA, Maniloff J, Desselberger U, Ball LA. London, Elsevier/ Academic Press; 2005:301-326.

2. Varma A, Malathi VG: Emerging geminivirus problems: $A$ serious threat to crop production. Ann Appl Biol 2003, 142:145-164.

3. Fauquet CM, Stanley J: Geminivirus classification and nomenclature: progress and problems. Ann Appl Biol 2003, 142:165-189.

4. Yadava P, Suyal G, Mukherjee SK: Begomovirus DNA replication and pathogenicity. Current Science 2010, 98:360-368.

5. Höfer P, Bedford ID, Markham PG, Jeske H, Frischmuth T: Coat protein gene replacement results in whitefly transmission of an insect non transmissible geminivirus isolate. Virology J 1997, 236:288-295. 
6. Paszkowski U, Zhang SB, Potrykus I, Paszkowski J: Replication of the DNA A component of African cassava mosaic virus in a heterologous system. J Gen Virol 1993, 74:2725-2729.

7. Etessami P, Saunders K, Watts J, Stanely J: Mutational analysis of complementary - sense of genes of African cassava mosaic virus DNA A. J Gen Virol 1991, 72:1005-1012.

8. Vionnet O, Pinto YM, Baulcombe DC: Suppression of gene silencing: A general strategy used by diverse DNA and RNA viruses of plants. P Natl Acad Sci USA 1999, 96:14147-14152.

9. Vanitharani R, Chellappan P, Fauquet CM: Geminiviruses and RNA silencing. Trends Plant Sci 2005, 10:144-151.

10. Vanitharani R, Chellappan P, Pita JS, Fauquet CM: Differential roles of AC2 and AC4 of cassava geminiviruses in mediating synergism and suppression of posttranscriptional gene silencing. J Virol 2004, 78:9487-9498.

11. Fauquet CM, Briddon RW, Brown JK, Moriones E, Stanley J, Zerbini M, Zhou X: Geminivirus strain demarcation and nomenclature. Arch Virol 2008, 153:783-821

12. Zhuo X, Liu Y, Calvert L, Munoz C, Otim-Nape GW, Robinson DJ, Harrison BD: Evidence that DNA - A of a geminivirus associated with severe cassava mosaic disease in Uganda has arisen by interspecific recombination. J Gen Virol 1997, 78:2101-2111.

13. Ndunguru J, Legg JP, Aveling TAS, Thompson G, Fauquet CM: Molecular biodiversity of cassava begomoviruses in Tanzania: evolution of cassava geminiviruses in Africa and evidence for East Africa being a center of diversity of cassava geminiviruses. Virology J 2005, 2:1-23.

14. Bull SE, Briddon RW, Ssserubombwe WS, Ngugi K, Markham PG, Stanley J: Genetic diversity and phylogeography of cassava mosaic viruses in Kenya. J Gen Virol 2006, 87:3053-3065.

15. Harrison BD, Zhou X, Otim-Nape GW, Liu Y, Robinson DJ: Role of a novel type of double infection in geminivirus induced epidemic of severe cassava mosaic in Uganda. Ann App Biol 1997, 131:437-448.

16. Fondong VN, Pita JS, Rey ME, de Kochko A, Beachy RN, Fauquet CM: Evidence of synergism between African cassava mosaic virus and a new double-recombinant geminivirus infecting cassava in Cameroon. J Gen Virol 2000, 81:287-297.

17. Pita JS, Fondong VN, Sangaré A, Otim-Nape GW, Ogwal S, Fauquet CM: Recombination, pseudorecombination and synergism of geminiviruses are determinant keys to the epidemic of severe cassava mosaic disease in Uganda. J Gen Virol 2001, 82:655-665.

18. Legg JP, Fauquet CM: Cassava mosaic geminiviruses in Africa. Plant Mol Biol 2004, 56:585-599.

19. Untiveros M, Fuentes S, Salazar LF: Synergistic interaction of Sweet potato chlorotic stunt virus (vinivirus) with Carla-. Cucumo-, ipomo-, and potyviruses infecting sweet potato. Plant Dis 2007, 91:669-676.

20. Vionnet O: RNA silencing as a plant immune system against viruses. Trends Genet 2001, 17:449-459.

21. Bisaro DM: Silencing suppression by geminivirus proteins. Virology 2006, 344:158-168.

22. Fondong VN, Chowda Reddy RV, Lu C, Hankoua B, Felton C: The consensus $\mathrm{N}$-myristoylation motif of a geminivirus AC4 protein is required for membrane binding and pathogenicity. Mol Plant Microbe Int 2007 20:380-391.

23. Ndunguru J, Legg JP, Fofana IBF, Aveling TAS, Thompson G, Fauquet CM: Identification of a defective molecule derived from DNA - A of bipartite begomovirus of East African cassava mosaic virus. Plant pathol 2006, 55:2-10

24. Stanley J, Frischmuth T, Ellwood S: Defective viral DNA ameliorates symptoms of geminivirus infection in transgenic plants. P Natl Acad Sci USA 1990, 87:6291-6295.

25. Patil BL, Dutt N, Briddon RW, Bull SE, Rothenstein D, Borah BK, Dasgupta I, Stanley J, Jeske H: Deletion and recombination events between the DNA - A and DNA - B components of Indian cassava - infecting geminiviruses generate defective molecules in Nicotiana benthamiana. Virus Res 2007, 124:59-67.

26. Mbanzibwa DR, Tian YP, Tugume AK, Mukasa SB, Tairo F, Kyamanywa S, Kullaya A, Valkonen JP: Genetically distinct strains of Cassava brown streak virus in the Lake Victoria basin and the Indian Ocean coastal area of East Africa. Arch Virol 2009, 154:353-359.
27. Winter S, Koerbler M, Stein B, Pietruszka A, Paape M, Butgereitt A: Analysis of Cassava brown streak viruses reveals the presence of distinct virus species causing cassava brown streak disease in East Africa. J Gen Virol 2010, 91:1365-1372.

28. Mbanzibwa DR, Tian YP, Tugume AK, Patil BL, Yadav JS, Bagewadi B, Abarshi MM, Alicia T, Changadeya W, Mukumbira J, Muli MB, Mukasa SB, Tairo F, Baguma Y, Kyamanywa S, Kullaya A, Maruthi MN, Fauquet CM, Valkonen JPT: Evolution of cassava brown streak disease - associated viruses. J Gen Virol 2011, 92:974-987.

29. Openshaw K: A review of Jatropha curcas: an oil plant of unfulfilled promise. Biomass Energy 2000, 19:1-15.

30. Gao S, Qu J, Chua NH, Ye J: A new strain of Indian cassava mosaic virus causes a mosaic disease in the biodisel crop Jatropha curcas. Arch Virol 2010, 155:607-612.

31. Monde G, Walangululu J, Winter S, Bragard C: Dual infection by cassava begomoviruses in two leguminous species (Fabaceae) in Yangambi, North Eastern democratic republic of Congo. Arch Virol 2010, 155:1865-1869.

32. Alabi OJ, Ogbe FO, Bandyopadhyay R, Lava KP, Dixon AGO, Hughes JA, Naidu RA: Alternate hosts of African cassava mosaic virus and East African mosaic Cameroon virus in Nigeria. Arch Virol 2008, 153:1743-1747.

33. Stanley J, Gay MR: Nucleotide sequence of cassava latent virus DNA. Nature 1983, 301:260-262.

34. Morinaga T, Ikegami M, Shimotohno K, Miura K: Total nucleotide sequences of the infectious cloned DNAs of Bean golden mosaic virus. Microbiol Immunol 1987, 31:147-154.

35. Sserubombwe WS, Briddon RW, Baguma YK, Ssemakula GN, Bull SE, Bua A, Alicai T, Omongo C, Otim-Nape GW, Stanley J: Diversity of begomoviruses associated with mosaic disease of cultivated cassava (Manihot esculenta Crantz) and its wild relative (Manihot glaziovii Müll. Arg.) in Uganda. J Gen Virol 2008, 89:1759-1769.

36. Maruthi MN, Seal S, Colvin J, Briddon RW, Bull SE: East African cassava mosaic Zanzibar virus - a recombinant begomovirus species with mild phenotype. Arch Virol 2004, 149:2365-2377.

37. Hong YG, Robinson DJ, Harrison BD: Nucleotide sequence evidence for the occurrence of three distinct whitefly - transmitted geminivirus in cassava. J Gen Virol 1993, 74:2437-2443.

38. Saunders K, Salim N, Mali VR, Malathi VG, Briddon R, Markham PG, Stanley J: Characterisation of Sri Lankan cassava mosaic virus and Indian cassava mosaic virus: evidence for acquisition of DNA B component by a monopartite begomovirus. Virology 2002, 293:63-74.

39. Berrie LC, Rybicki EP, Rey ME: Complete nucleotide sequence and host range of South African cassava mosaic virus: further evidence for recombination among begomoviruses. J Gen Virol 2001, 82:53-58.

40. Rothenstein D, Haible D, Dasgupta I, Dutt N, Patil BL, Jeske H: Biodiversity and recombination of cassava - infecting begomoviruses from Southern India. Arch Virol 2006, 151:55-69.

41. Bock KR, Guthrie EJ, Figueiredo G: A strain of Cassava latent virus occurring in coastal districts of Kenya. Ann Appl Biol 1981, 99:151-159.

42. Aswatha Narayana DS, Rangaswamy KS, Shankarappa MN, Maruthi MN, Reddy CNL, Rekha AR, Murthy KVK: Distinct Begmoviruses closely related to cassava mosaic viruses causes Indian Jatropha Mosaic Disease. Int J Virol 2007, 3:1-11.

43. Raj SK, Snehi SK, Kumar S, Khan MS, Pathre U: First molecular identification of begomovirus in India that is closely related to Cassava mosaic virus and causes mosaic and stunting of Jatropha curcas L. Australas Plant Dis Notes 2008, 3:69-72.

44. Raj SK, Kumar S, Snehi SK, Pathre U: First report of Cucumber mosaic virus on Jatropha curcas in India. Plant Dis 2008, 92:171.

45. Lozano G, Trenado HP, Valverde RA, Navas-Castillo J: Novel begomovirus species of recombinant nature in sweet potato (Ipomoea batatas) and Ipomoea indica: taxonomic and phylogenetic implications. J Gen Virol 2009, 90:2550-2562.

46. Were HK, Winter S, Maiss E: Viruses infecting cassava in Kenya. Plant Dis 2004, 88:17-22.

47. Were HK, Winter S, Maiss E: Distribution of begomoviruses infecting cassava in Africa. J Plant Pathol 2003, 85:145-151. 
48. Behjatnia SA, Dry IB, Rezaian MA: Characterisation and transient replication of Tomato leaf curl virus defective DNA. Arch Virol 2007, 152:1127-1138.

49. Monger WA, Seal S, Cotton S, Foster GD: Identification of different isolates of Cassava brown streak virus and development of a diagnostic test. Plant Pathol 2001, 50:768-775.

50. Choi SK, Choi JK, Park WM, Ryu KH: RT-PCR detection and identification of three species of cucumoviruses with a genus - specific single pair of primers. J Virol Methods 1999, 83:67-73.

doi:10.1186/1743-422X-8-386

Cite this article as: Ramkat et al.: Biotechnological approaches to determine the impact of viruses in the energy crop plant Jatropha curcas. Virology Journal 2011 8:386.

\section{Submit your next manuscript to BioMed Central} and take full advantage of:

- Convenient online submission

- Thorough peer review

- No space constraints or color figure charges

- Immediate publication on acceptance

- Inclusion in PubMed, CAS, Scopus and Google Scholar

- Research which is freely available for redistribution

Submit your manuscript at www.biomedcentral.com/submit 